\title{
Undergraduate dental students' perspectives about experiences in primary care for their education in the field of health
}

Pedro Augusto Thiene Leme ${ }^{1}$

Antônio Carlos Pereira ${ }^{1}$

Marcelo de Castro Meneghim ${ }^{1}$

Fábio Luiz Mialhe ${ }^{1}$

${ }^{1}$ Faculdade de Odontologia de Piracicaba, Universidade Estadual de Campinas. Av. Limeira 901, Areião. 13414903 Piracicaba SP Brasil. pedroleme3@gmail.com

\begin{abstract}
Supervised training periods in primary care have been used as spaces for teaching and extension in the area of health, making it feasible to include undergraduates in concrete teaching-learning scenarios. The aim of this study was to analyze the perceptions of dental students about the importance of supervised training periods in Family Health Units to their professional education. The sample consisted of 185 students who answered the question: What is your opinion about the importance of this training period in SUS to your professional education? Comment on this experience and its positive and negative aspects The responses were analyzed by the quali-quantitative Collective Subject Discourse (CSD) technique. The students appreciated learning through practice in the service; contact with professionals from other areas; opportunity for technical-operative improvement and demonstrated sensitivity in the face of social reality, although they appeared to be concerned about being absent from the faculty, arguing that they were being prejudiced as regards their intramural clinical productivity, exhaustively demanded of them. It was concluded that students placed value on the extramural experience, however, it was perceived that there was still a predominant influence of focus on intramural clinical training.
\end{abstract}

Key words Education, Staff development, $\mathrm{Na}$ tional Health Programs, Family Health 


\section{Introduction}

The concern about professional education in the area of health has been the target of discussions in the world academic medium since the beginning of the last century ${ }^{1-5}$. In spite of there being regional differences where courses are included, which reflect the distinct structures of the health services and academic organizations, there is universal recognition of the need for renovation in professional education, which comprises the incorporation of biospychosocial understanding of the health-disease process, and produces significant changes in the levels of health in the collective sphere ${ }^{6}$.

In Brazil, the concern with education in the area of health was the object of the First National Human Resources Congress in 1986, and since then the importance of the relationship between professional education and the public health system in our country has been established ${ }^{6}$. At the time, the need was determined for reorganization of the policies of management and education in health, by means of teaching-service integration and assistential models located in concrete spaces-populations.

The creation of the Family Health Program (FHS in 1991, generated a demand for professionals in the different areas of health, who would be able to work within the philosophy of the strategy, starting with an broadened process of work that would break away from the biomedical model. However, as an indirect consequence, this fact ended up showing evidence of failures in the professional education of doctors and nurs$\mathrm{es}^{7}$. The same occurred as regards the incorporation of the dental surgeon into the Family Health Team (FHT) in the year 2000, by means of Administrative Ruling $1.444 / \mathrm{GM}^{8}$, which brought to light questions concerning the quality of education of this professional for this new market.

Since then, a series of events have arising in the Federal sphere, such as the promulgation of the National Curricular Guidelines (NCG) in 2002, National Program for Reorientation of Professional Education (Pró-Saúde), in 2005, Program of Education for Work in Health (PETSaúde), in 2008, among others, that have led to inducing chances in the curricula of courses in the area of health throughout the country, including dentistry ${ }^{6,9,10}$.

One of the most difficult approaches of this generalized movement of reformulation of professional education in health was the integration of teaching-service, by means of supervised training periods in extramural environments, with the early inclusion of undergraduates in real places of attendance to the population during their education, which would extrapolate the physical limits of the faculties, and where they would potentially be able to perform extraclinical skills, considering the biospychosocial demands of their work $^{1,11,15}$.

According to the Brazilian Association of Dental Teaching ("Associação Brasileira de Ensino Odontológico" - Abeno), the supervised training period is an instrument for integration of the student with the social, economic and work reality. It should place the future professional into contact with the diverse social realities; is characterized by the full attention to the patient, and is the focus of work by students on education and health promotion until reversal of the damage ${ }^{16}$.

The supervised training period encompasses activities that may be performed in intra- or extramural clinics, and in public or private services, in the presence or absence of an external preceptor ${ }^{16,17}$, with its organization being under the responsibility of each faculty.

This type of experience, depending on the implementation format, is pointed out as being capable of arousing in the student, the reflection about social questions that permeate dentistry; encourage consciousness related to aspects of politics and citizens; broaden the students vision and better prepare him/her for work in the public sector ${ }^{18}$.

In spite of having reappeared more forcefully in the 2000s, the notion of extramural teaching is considered to have originated in the seminars of Viña del Mar (Chile) and Tehuacán (Mexico), in 1955 and 1956, respectively, both organized by the Pan-American Health Organization ${ }^{19}$.

Recently, the resumption of interest in training periods was related to the appearance of the National Curricular Guidelines (NCG) for the areas of health, made feasible by the Law of Guidelines and Bases of National Education of 1966. The NCG for dental courses, approved by the National Council of Education (NCE) in 2002, in its seventh article, states that ${ }^{9}$ :

"The education of the Dental Surgeon must guarantee the development of curricular training periods, under docent supervision. This training period must be developed in an articulated manner and with growing complexity throughout the process of education. The minimum hourly load of the supervised curricular training period must attain $20 \%$ of the total hourly load of the Undergraduate Course in Dentistry proposed, based on the specific Report/Resolution of the Chamber of Higher Education of the National Council of Education". 
The NCG of the courses in nursing, phonoaudiology, physical therapy and nutrition, each have a very similar paragraph that basically presents the same requisites, while the guidelines for the course in medicine point out a minimum of $35 \%$ of the total hourly load of undergraduation destined to the training periods ${ }^{20}$.

Although the NCG indicate these proportions of hourly loads for the training periods, they do not clearly state the criteria that qualify these activities. That is, as has been problematized by Werneck et al. ${ }^{17}$, the term curricular training period generally encompasses qualitatively distinct activities in the various courses.

This fact appears to repeat itself in the context of dental teaching, with the result that the idea that "any training period is valid" is so consolidated, that ABENO itself has legitimized this discourse in the "Guidelines of ABENO for the definition of the supervised training period in Courses in Dentistry"16. Paradoxically, in the middle of a progressist discourse about training periods - "[...] is the instrument of the student's integration and knowledge with the social and economic reality of his/her region and the work in his/her area. [...] understood as being full attendance of the patient [...] it must encourage the relationship of teaching-services and extend the relations of the university with society"; - the document signals, without ponderation, a series of places that may compose the minimum hourly load of the supervised training periods, encompassing activities that are very distinct among them: “[...] understood as being attendance [...] intra and extramural [...] multidisciplinary and in public and private care services [...] The holiday, emergency clinic and triage shifts may be considered to be supervised training periods. In the extramural activity, the student will perform all the activities pertinent to a health profession$\mathrm{al}$, with direct or indirect docent supervision, and there may be an external preceptory"15. As problematized by Werneck et al. ${ }^{17}$, the indistinctness of the role of each teaching-learning scenario ends up endorsing the continuity of traditional, technicist and biologicist practices within the curricula.

As a result, this places the main changes proposed by the NCG in check, particularly those contained in the single paragraph: "The education [...] must contemplate the health system in force in the country, full health care in a regionalized and hierarchized system of reference and counter-reference and team work" - and in the 6th article: "The essential contents [...] must be related to the entire health-disease process of the citizen, family and community, integrated with the epidemiological and professional reality $[\ldots]$ ". 9 . It is not difficult to find the distance between these propositions and the limited potentiality of the experiences provided by a curriculum with predominance of intramural experiences.

Thus, it appears that there is still a representation shared by many managers and educators in the area of dentistry that the concomitant presence of a dental office, teeth and/or gums, a student dentist and someone who supervises him/her (namely, a dentist-professor, at one time trained according to the same model), operating structured knowledge, would even today be sufficient elements for conducting the "training periods". In addition, there would be no differentiation about whether this activity would be performed, for example, within the faculties, under the weight of the institution and closed to the real world; or within a Family Health Unit, inserted into a community context, with its team of workers and particularities.

On the other hand, there are various national and international studies that have verified positive aspects arising from extramural activities, with emphasis on the importance of students being in contact with activities that provide them with the perception of the types of problems and demands of the population that does not frequent intramural clinics. In addition, there are the aspects of gaining understanding of the conditions of access to services; experience of the strategy of home visits, revelation of the relations between living conditions and conditions of health; increase in the importance given to preventive and health promotional procedures; the incentive to conduct research, interdisciplinarity, motivation to perform community practices and health education, among others ${ }^{14,21-23}$.

In spite of the existence of reports, it has been verified that up to now, there is a scarcity of qualitative studies in the area of dentistry, which evaluate the perception of students about the experiences undergone in these real scenarios of practices $^{24}$. This type of evaluation is important, because it allows one to identify the students' point of view of the experiences they have undergone, and their respective arguments, with the potential to reveal aspects that were not presumed in the construction of instruments of the closed questionnaire type, in addition to providing a wealth of details when preserving the narrative nature of the statements.

Considering the foregoing discourse, the aim of this study was to analyze the perceptions of dental students about the supervised training 
periods in Family Health Units (FHUs), for their professional education.

\section{Methodology}

The present study was approved by the Research Ethics Committee of FOP-Unicamp. In this study of a qualiquantitative nature, 184 dental students from a public dental school in the State of São Paulo participated. They comprised $86.8 \%$ of the universe of 212 students who had participated in the training period activities performed in FHUs during the last two semesters of the course, in the years 2008, 2009 and 2010. The extramural discipline occurred in the last two semesters of the undergraduate course analyzed, and was connected with the integrated clinic discipline.

Extramural activities are composed of two distinct contexts, both made feasible by means of partnership between the Municipal Secretary of Health (MSH) of Piracicaba/SP and the dental school. The first refers to clinical attendance of schoolchildren, performed in the clinics of the old faculty building, located in the city center, which also houses a municipal Dental Specialties Center (DSC). The undergraduates attended children in the age-range between 6 and 12 years, from public schools in the municipality, under the supervision of professionals of the MSH and faculty members, in a context that is close to the real work in specialized secondary care in pediatric dentistry. The second context of development of extramural activities is performed in the FHU, object of analysis of this study.

Although the training period in the FHUs was situated within a clinical discipline common to the traditional areas (such as periodontology and dentistry, for example), there was exclusive participation of the professors and post-graduate students from the area of preventive dentistry and public health, without involvement of any of the other departments. Supervision and follow-up of the students' evaluation was performed directly (presential) and indirectly (at a distance) by the docents and post-graduation students of the mentioned area, in addition to the members of the Family Health Teams and municipal health sector managers.

Before each semester of the school year began, the department responsible for the training period, selected the FHU for each student by draw (6, from among the 34 existent in the Municipality of Piracicaba, SP, up until then, partners in professional education) and the weeks during which the students would perform the activity. Therefore, the six units received a different undergraduate every week. In the following semester, the students fulfilled the same hourly load (40h), in the same unit, totaling $80 \mathrm{~h}$ during the quarter, and up until then, the last year of the undergraduate course.

On the first day of the students' contact with the FHU, the students met with the team in order to be informed of their work, resolved doubts about the logistics used, the work time schedule of the FHU, activities in which they had to participate, and identified the work of the professionals within their specified field of work. At this time, the time schedule of the students' activities within the FHU was presented, which could be discussed and changed according to the demands of each period of time.

Thus, under the supervision of the preceptor health professionals, post-graduate students and professors, the undergraduates planned and formed groups for discussion about oral health with the population, home visits with the Community Health Agents, weekly team meetings, clinical attendances, provided schoolchildren with oral health care, worked on territorialization and epidemiological surveys. In the services the preceptors followed up all the weekly activities, including attribution of scores with regard to the undergraduates' interest and initiative, their punctuality and frequency, integration and participation with the team, technical aspects, receiving users, gaining knowledge about aspects connected with SUS and FHP, clothing and appearance, ethical posture, among other issues, which influenced the score attributed to the students' performance ${ }^{22,25}$.

On a daily basis, the students filled out the "Log Book", a digital platform in which they inserted information about what they did in the unit in that week, in order to provide continuity of the work previously developed, by the next student who would work at the Unit ${ }^{22,25}$.

At the end of the training period, the students filled out an evaluation chart of the experience, composed of the following question: "What is your opinion about the importance of this training period in SUS to your professional education? Comment on this experience and its positive and negative aspects".

For data analysis, the qualiquantitative data processing of the collective subject discourse technique $^{26}$, based on the Theory of Social Representations ${ }^{27}$. was used. The method considers the aim of the study (opinion of a group), a variable that is simultaneously qualitative and quantitative. It is qualitative because, according to 
Lefèvre $^{28}$, what people have to say must be treated as an unknown, and quantitative, because the opinions have different degrees of sharing within the studied group, which is capable of being measured.

Collective Subject Discourse (CSD) is a method of analysis of open responses which, at the end of the process, results in collective statements, written in the first person singular, made by means of different individual statements, with a view to producing the effect of the collective expressing itself directly ${ }^{28}$. In addition to the CSD, the final result of a research of this nature also comprises the degree of sharing (DS), which numerically represents the proportion of persons who share a similar idea and the central ideas (CI) identified. The CI is a linguistic expression the researcher designates to describe in the shortest and most direct way possible, the meaning of the individual discourses (or stretches of discourses), which enables similar ideas to be organized in a CSD. These results are obtained by means of a series of operations of data organization in the form of text, aided by the Qualiquantisoft software program.

In researches of a qualitative nature, it is opportune to perform the stage of validation together with the issuers of the information, which may be done by showing the participants the collective subject discourses constructed by means of the analysis, so that they might recognize and confirm them, and comment on the findings ${ }^{26}$. However, this procedure could not be carried out in the present research, because the final analysis was started and concluded when all the students had already graduated over two years previously, a fact that made it unfeasible for the researcher to contact them, allied to the possibility of bias of memory by the interviewees.

\section{Results}

In Table 1, the quantitative data are presented from the synthesis of the central ideas and their respective frequencies of manifestations obtained from the undergraduates' responses. The respective CSDs are set out below.

The discourses of the collective subject with reference to the central ideas were as follows:
Table 1. Synthesis of central ideas and respective frequency of manifestations as regards question "What is your opinion of the importance of this training period at SUS to your professional education? Comment on this experience and its positive and negative aspects".

\begin{tabular}{lcc}
\hline \multicolumn{1}{c}{ Central Ideas } & n & $\%$ \\
\hline $\begin{array}{l}\text { A. It was positive to experience the } \\
\text { service in practice }\end{array}$ & 118 & 64.1 \\
$\begin{array}{l}\text { B. It was positive to get to know the } \\
\text { social reality }\end{array}$ & 90 & 48.9 \\
$\begin{array}{l}\text { C. It was positive to come into contact } \\
\text { with professionals of other areas }\end{array}$ & 52 & 28.3 \\
$\begin{array}{l}\text { D. It was negative because it interfered } \\
\text { in clinical production }\end{array}$ & 29 & 15.8 \\
$\begin{array}{l}\text { E. It was positive from the aspect of } \\
\text { technical dentistry }\end{array}$ & 27 & 14.7 \\
\hline
\end{tabular}

Note: the sum of the frequency of central ideas extrapolates the number of 184 responses and the percentage of $100 \%$, as one and the same individual may have presented more than one central idea.

\section{Discourse of the collective subject on the central idea A (It was positive to experience the work in practice)}

It was interesting to learn in practice how SUS works, to be able to see the day to day activities of the unit, get to know the Family Financial Grant (BF) better, the hierachization, systems of reference and counter-reference, the support network is spectacular, it was essential. Here I did everything, helped in the infirmary, dental office, weighing children, attendance to the population, I made visits with the CHAs, helped in post-natal and elderly persons' consultations, participated in meetings to discuss the local oral health problems and possibilities of improving the service provided. All this was good for becoming more mature, and see a little of how life is outside the faculty. I could make a bridge of connection between what I learned in the classroom about the working and guidelines of a FHU! By going there, experiencing, you learn much more than you do only in theory at the faculty, I could completely understand various of the abbreviations, which I could never even remember. Learning how to work in public service is not taught at the faculty, and many of us probably will have our employment sustained by it. We have to have practical social dentistry in order for us to be sure whether we like it or not. I consider important, any and every experience that stops being a role and becomes reality, it was able to awaken in us the initiative of working for this group of per- 
sons, this experience changed my conception with respect to public service. It was marvelous, in spite of me being a little reluctant at first, minutes after arriving there, I saw that there was some purpose in that and I opened myself to all the experiences. This experience was, and will still be very important, I thank all those who contributed to this.

\section{Discourse of the collective subject on the central idea B (It was positive to get to know the social reality)}

It was a shocking experience, I thought it important, because I saw a hard reality, different from that to which I am accustomed. It is an experience of consciousness raising of the students because the reality these people live is not the one we experience in the faculty clinic. At the post, they are treated not only as sick people, that is, in addition to the employees treating the disease, the people receive specialized and humanitarian treatment in a complete and adequate manner, and are embraced. Many only want to talk and unburden themselves. This experience revealed to us the social and relationship side of our work, the area of health requires a vast experience in the requisite of human relations. I began to have more desire to help people, and see a patient not only by the mouth that needs treatment, but also by the life, socioeconomic and cultural conditions, as a whole, inserted in a global situation, being influenced by the social, family and personal sphere. A health professional must have a notion of the medium in which his/her patient lives in order to promote health, I could see what the origin was, of the "problem" that arrived at the clinic, dental office. I am sure that all this will be of great value, in order to know how to live with the differences, arousing in us a feeling not only of humility, but of being able to do something to try and minimize the suffering of this population that is so socially excluded. It is marvelous being able to help needy people and be rewarded with care and affection.

\section{Discourse of the collective subject on the central idea $\mathrm{C}$ (The contact with professionals from other areas was positive)}

To me, as a professional it added the opportunity to see the integration of a team, perceive that it is very important for the solution of the population's health problems. It was positive to improve the capacity to work in a group, practice interdisciplinarity, leaving aside a little the "individualist" aspect of the clinical environment. I learned to work in a team, because the patient belongs to all the professionals in the unit. At the weekly meeting, I could perceive how the topics and doubts/suggestions are exposed and discussed with all the staff, I thought it very important to feel how fundamental the interaction of all of them is with regard to the patients. The team is marvelous, I liked the company very much, the laughter. I perceived that the FHP would not work without the action of the Community Health Agents, and that they are the ones who bring the population to the unit.

\section{Discourse of the collective subject on the central idea D (It was negative because it interfered in clinical production)}

Having to lose clinical hours to do extramural work was a negative aspect. In the integrated dental clinical at the faculty, the minimum production demanded is excessive, they could retain the training period in a manner that it would not prejudice us in this regard, being absent from the clinic the whole week is very complicated. The way the teaching system is at our faculty, does not allow us to take advantage (of the experience) psychologically, because we are there, with our mind on the clinic(al time) we are losing, if the training period did not prejudice the students so much, it would be recognized to a larger extent. There should be a better (way) to conciliate the periods of time. The negative aspects are caused more by the pressure the clinic imposes on the students, than by the training period itself. For persons who do not intend following (a career) in the public health medium, it ends up being useless spending so much time in the units with so much content being passed on by the faculty. I lost the clinical (time) delayed a prosthesis, and this perhaps caused me an exam.

\section{Discourse of the collective subject \\ on the central idea $\mathrm{E}$ (It was positive from the aspect of technical dentistry)}

It was positive to follow up the activities of everyone at the unit because it enriched us with specific dental knowledge, learning new techniques, getting to know a work environment different from that experienced within the faculty, which makes the student capable of attending under different conditions. I performed procedures which I had not performed at the faculty, such as amalgam restorations, I learned some things from the dentist, the speed and rapidity with which we performed to procedures, the contacts with professionals who are already working in the area ended up passing a little experience on to us. I performed many fluoride applications at the schools! Even without many resources, such as for example, not having material 
for absolute isolation, it is possible to perform the procedures and do so efficiently.

\section{Discussion}

The aim of the present study was to evaluate the perceptions of students about the importance of the supervised training period at Family Health Units to their professional education, by means of a qualiquantitative research.

In the discourses it was possible to identify elements that placed a value on the potential of the training period to promote reflections and experiences important to the students, about the practical experience in SUS, social reality, team work, benefits of incorporating a scenario outside that of the faculty, and about the teaching-learning process. These findings are stimuli, so that there will be incorporation of similar activities in the various undergraduate course in the area of health.

There is a consensus in the literature about the incorporation of practical teaching activities in real teaching-learning scenarios ${ }^{29-33}$. The students' receptivity of the experience, associated with the arguments about overcoming academic theoricism, expressed in the CSD A, confirmed the need for incorporating learning experiences based on concrete situations of the health services. The students' appreciation of the experience is in line with that recommended by the "program Pró-Saúde", on its axis that deals with practical scenarios, which foresee the exposure of students to working on real problems $s^{6}$. In the discourse, one also notes the perception of the importance of practice in making meaningful the theoretical learning seen in the classroom, clarifying collective health concepts, which was also found by Moimaz et al. ${ }^{34}$ in a study that evaluated the importance of the extramural training period for professional education conducted in the city of Araçatuba. In another study, Sanchez et al. ${ }^{18}$ evaluated the wishes, perceptions and preparation of dental students with regard to the principles of the FHP, finding that the majority of students affirmed that the acquisition of desirable characteristics for good work in the program came about by experiencing the reality, which also corroborates our findings. On the other hand, Daher et al..$^{24}$ found that the students' interest in practical extramural activities appeared to diminish when repeated visits are made, fostering the hypothesis that it is necessary to think of innovating and stimulating activities in successive contacts with the service.
The central idea $\mathrm{B}$ and its respective CDS showed that the experience gained in the training period provided students with the revelation of social reality and appeared to cooperate with the construction of a humanist and understanding view of health problems, questions directly associated with the characteristics desired as part of the graduate's profile, pointed out in the NCG'. It is necessary to point out, however, at the end of the discourse, the unfolding of an idea may be interpreted as an indication of charity. This may be related to a lack of understanding by some students that health care in Brazil is a right, and not a benevolence. This finding corroborates the affirmation of Lemos ${ }^{35}$ that dental care of the low income population is considered by many dental students and professionals as charity and philanthropy.

In the study of Sanchez et al. ${ }^{18}$, the authors found that the experience of students in the face of extramural reality and shocking social scenarios provided them with better understanding about the determinants that impact on the context of patients' lives, thereby cooperating with their professional education. Moimaz et al. ${ }^{36}$, in a study that evaluated extramural dental service (Semo), from the point of view of graduates, found that the students considered contact with the social reality to be one of the factors related to the contribution of the training period to professional education.

Along the same line, in an evaluation about the perception of dental students as regards home visits, Morita et al. ${ }^{37}$ found the acquisition of attributes such as a broadened view of the health-disease process, recognition of the importance of the tie with and reception of users in health care, similar to the findings of this study. Rubin $^{38}$ also found the acquisition of competences such as appreciation of the community spirit and broadened cultural understanding after performing activities in public health services. These findings militate in favor of the importance of this type of activity in promoting the acquisition of these key attributes in the efforts of professional reorientation.

The positive experience of multiprofessional work, observed in CSD C confirms the findings of other studies that indicated that the importance of team work was understood and appreci-

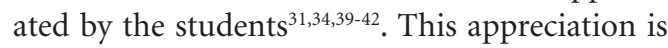
surprising, because in the environments of clinical practice at the faculty, the isolated work of the professional prevails, as it does in private practice, towards which the focus of education is still predominantly directed. In Brazil, the inclusion of the dentist in family health teams demands a 
posture that breaks this paradigm, in which the professional acts in a manner isolated from other health professionals. After all, team work should not be understood simply as the concomitant action of different professionals, there must in fact be communication and integration ${ }^{42}$.

Various points in the CSDs indicated the need for an education directed toward multidisciplinarity, interdisciplinarity, multiprofessionalism, skills for communication with the team, among others ${ }^{8}$. Similar points are present in the recommendations of the Association for Dental Education in Europe (ADEE), indicating that on graduation, the European Dentist must be prepared to work in a team with his/her peers and with other professionals in the health system in force ${ }^{43}$. The commitment of the team reported by the students in this study differs from that found by Daher et al. ${ }^{24}$, who identified the report of lack of commitment by the team in an extramural training period in the FHP with focus on pediatric dentistry, conducted in the State of Goiás, with this being a factor associated with negative experiences had by the students.

In spite of the advancements, it was verified that some institutional barriers may prejudice the evaluation of the experience undergone by the students, a fact observed by the CSD D, with reference to the perception of students that the training period hampered the performance of clinical activities at the faculty. This fact appears to be related to the idea that the training period is a parallel, less important activity and not part of the cycle of education. This may be associated with the fact that its implementation takes place by the priority, if not the isolated effort of the disciplines of collective health, in addition to the students' fragmented view between private and public practice, reinforced by the extensive hourly load of intramural clinics. According to Lefèvre and Lefevre ${ }^{26}$, the social representations are influenced by conditions relative to historical context and infrastructure, and citing Bauman ${ }^{44}$, who put it that the prevailing historical context is that of the globalized world, in which social educations are present, characterized in the plane of infrastructure by the principle of individualized consumption. This context is echoed within the process of education, fostering the trend towards preparation for the market practice, removed from the context of the epidemiological needs of the population.

Although intramural clinics are a fundamental item of equipment included in disciplines in the curriculum, the capacity and technical skill for the treatment of diseases - the priority focus in this scenario - cannot be the only end objective in the education of health professionals $\mathrm{s}^{42}$. The prioritization of intramural clinics reflects the Flexnerian vision of education that places value on the centrality of compartmentalized, hardly integrative technical knowledge, marked by the biologicist and unicausal vision of disease, in detriment to the contextual determinants ${ }^{45}$.

Finally, the CSD E reveals the value students placed on the opportunity of learning about and improving technical skills in a scenario outside the faculty, in contact with experienced professionals, in addition to the demystification of the need to have very sophisticated resources in order to perform good work. This finding is in agreement with diverse studies that have proved the increase in motivation, confidence and efficiency of clinical skills in extramural practices ${ }^{30,46,47}$. Although learning technical skills is not the only, or even the most important objective of this type of training period, perhaps the discovery of it being possible to learn and apply clinical interventions in other contexts of practices, and also obtaining a good clinical results, may attract the students' liking for work in SUS. In the study of Santa-Rosa et al. ${ }^{48}$, the students who participated in the rural training period showed surprise on finding an adequate infrastructure in which to perform clinical practice. Here, the students also placed value on the opportunity to work at the FHU, on cases that are uncommon in the intramural clinics at the faculty, a findings similar to those of other studies, in which the undergraduates evaluated the extramural experience as an opportunity that exposed them to a larger diversity of clinical demands, such as they would not have the opportunity to find in the internal environment of the faculty $y^{46,47,49,50}$.

The curriculum of the faculty in question presents a cycle of training periods composed of extramural activities (in the FHUs, together with the DSC) and also by the training period in the intramural clinic, initially composed of the isolated disciplines of surgery, periodontics, prosthesis and later, of the integrated clinics, in addition to the emergency shift and triage service, with ample predominance of the work load dedicated to these activities performed within the physical limits of the faculty. Taking as a theoretical reference the problematization proposed by Werneck et al. ${ }^{17}$, we affirm that the composition of the training period activities is marked, above all, by conservative practices, and the training period in the FHU remains isolated as an activity of experiencing the real world of work in the national health service (SUS). In this sense, in view of the 
results obtained, although we are optimistic with regard to the depth of reflection demonstrated in the discourses of the students and the formation of a broad view, we believe that changes of paradigm in the profile of professionals will demand institutional debates and much broader curricular reformulations, which would be an enormous challenge, considering the political context of the academies, and the professional identity of dentistry itself, according to Warmling et al. ${ }^{51}$, by the autonomy of the mouth and predilection for liberal private practice.

Therefore, as the curriculum of dental education was born without mention of the inclusion of an oral clinic (only surgery and prosthesis), today the curriculum in a certain way reaffirms this autonomy by isolating the teaching of dentistry from the other areas of health, and above all, from society and from the real world of work, which is in line with a tradition of over 130 years ${ }^{51}$.

By analysis of the undergraduates' discourses, we consider that the experience developed in the FHUs presents strong points, such as the inclusion of the undergraduate in the real world of work in collective health, the interaction with concrete populations that presented a demand for their work, participation in diversified multiprofessional activities and effectiveness of the docent-municipal assistential integration, with the participation of the network in both the supervision and evaluation of students, and in post-graduation courses together with the faculty. On the other hand, the weak points reside in the fact of the small hourly load dedicated to this purpose, the experience in parallel to the predominant influence of intramural education, curricular isolation and lack of interest in participating in this activity, on the part of the staff members not belonging to the area of collective health.

Although the training period in the FHUs is inserted in a traditional curricular context marked by emphasis on intramural clinical practices, destitute of any type of integration with the other departments, the findings indicate the importance of the training period in making it feasible for students to gain experiences, reflections and the development of skills, which would not be possible to develop in the intramural activities. Although staying in a FHU for one week, of itself does not represent a revolution in professional education, it did provide the students with an important opportunity to get to know the work of the public sector, broadened their awareness of the social reality and their experience with multiprofessional work, factors that do not exist in intramural clinics.
The present study has some limitations. One of these results from the fact that the evaluation charts were applied by the department responsible for the training period, which, in hypothesis, could generate some type of reluctance by the students to express negative aspects of the training period. However, this fact does not disqualify the important positive findings because, by the methodology used, it was possible to preserve argumentative aspects, including negatives ones, which collaborated with legitimizing the discourses. Another limitation that deserves to be pointed out results from the use of the term "importance" in the question put to the students ("What is your opinion about the importance of this training period at SUS to your professional education? Comment on this experience and its positive and negative aspects". Although it was the authors' intention to use this term in the sense of value, merit or interest ${ }^{52}$, we consider that its use may have been interpreted by the students in order to induce them to favor the positive aspect of the training period, so that it is a potential bias ${ }^{26}$.

The fact that some students participated in the training period in the last months of the course made it difficult to perform the analysis in an adequate time frame to provide devolution and validation of the discourses obtained from the students. However, considering the recent trend of faculties to insert undergraduates in the first semesters of the course in primary health care activities, which has been recommended in the national sphere $\mathrm{e}^{6,9,10}$, it is suggested that future studies contemplate this stage, which would contribute to broadening the understanding of the present findings. Moreover, evaluations developed by members outside of the department could contribute to greater faithfulness of the data.

\section{Conclusion}

In this study it was observed that the undergraduates attributed positive importance to the training period in the FHUs for their professional education. The qualiquantitative analysis pointed out that the undergraduates were capable of appreciating the practical experience in the service, the knowledge of social reality, contact with professionals from other areas, and technical training under conditions differing from those found in the faculty, although they demonstrated concern about the interference in their intramural clinical production. 


\section{Collaborators}

PAT Leme, AC Pereira, MC Meneghim and FL Mialhe participated equally in all the stages of preparing the article.

\section{References}

1. Zilbovicius C, De Araujo ME, Botazzo C, Frias AC, Junqueira SR, Junqueira CR. A Paradigm Shift in Predoctoral Dental Curricula in Brazil: Evaluating the Process of Change. J Dent Educ 2011; 75(4):557-564.

2. Hobson RS. A view of European challenges in dental education. Br Dent J 2009; 206(2):65-66.

3. McHarg J, Kay EJ. The anatomy of a new dental curriculum. Br Dent J 2008; 204(11):635-638.

4. Bailit HL, Formicola AJ, D’Abreu KC, Bau I, Zamora G, Stavisky JS. The Dental Pipeline Program: The National Program Office Perspective. J Dent Educ 2009; 73(Supl. 2):S15-S22.

5. Kassebaum DK, Hendricson WD, Taft T, Haden NK. The Dental Curriculum at North American Dental Institutions in 2002-03: A Survey of Current Structure, Recent Innovations, and Planned Changes. J Dent Educ 2004; 68(9):914-931.

6. Brasil. Ministério da Saúde (MS). Ministério da Educação (MEC). Prograna Nacional de Reorientação da Formação Profissional em Saúde. Pró-Saúde: objetivos, implementação e desenvolvimento potencial. Brasília: MS; 2007.

7. Kanno NP, Bellodi PL, Tess BH. Profissionais da Estratégia Saúde da Família diante de demandas médico-sociais: dificuldades e estratégias de enfrentamento. Saude Soc 2012; 21(4):884-894.

8. Brasil. Portaria 1.444 , de 28 de dezembro de 2000. Estabelece incentivo financeiro para a reorganização da atenção à saúde bucal prestada nos municípios por meio do Programa de Saúde da Família. Diário Oficial da União 2000; 29 dez.

9. Brasil. Conselho Nacional de Educação; Câmara de Educação Superior. Resolução CNE/CES 3, de 19 de fevereiro de 2002. Institui Diretrizes Curriculares Nacionais do Curso de Graduação em Odontologia. Diário Oficial da União 2002; 4 mar.

10. Brasil. Portaria Interministerial $\mathrm{n}^{\circ} 1802$, de 26 de Agosto de 2008. Institui o Programa de Educação pelo Trabalho para a Saúde: PET-Saúde. Diário Oficial da União 2008; 27 ago.

11. Schönwetter DJ, Law D, Mazurat R, Sileikyte R, Nazarko O. Assessing graduating dental students' competencies: the impact of classroom, clinic and externships learning experiences. Eur J Dent Educ 2011; 15(3):142-152.

12. Mascarenhas AK. Community-Based Dental Education at Boston University. J Dent Educ 2011; 75(Supl. 10):S21-S24.

13. Lynch CD, Ash PJ, Chadwick BL, Herbert RA, Cowpe JG. Developing the continuum of dental education: including dental foundation trainers in the delivery of a community-based clinical teaching programme. Brit Dent J 2012; 213(10):517-521.
14. Okayama M, Kajii E. Does community-based education increase students' motivation to practice community health care? - a cross sectional study. BMC Med Educ 2011; 11:19.

15. Piskorowski WA, Fitzgerald M, Mastey J, Krell RE. Development of a Sustainable Community-Based Dental Education Program. J Dent Educ 2011; 75(8):10381043.

16. Associação Brasileira de Ensino Odontológico. Diretrizes da ABENO para a definição do estágio supervisionado nos cursos de Odontologia. Rev ABENO 2002; 2(1):39.

17. Werneck MAF, Senna MIB, Drumond MM, Lucas SD. Nem tudo é estágio: contribuições para o debate. Cien Saude Colet 2010; 15(1):221-231.

18. Sanchez HF, Drumond MM, Vilaça EL. Adequação dos recursos ao PSF: percepção de formandos de dois modelos de formação acadêmica em odontologia. Cien Saude Colet 2008; 13(2):523-531.

19. Casotti E. Odontologia no Brasil: uma (breve) história do pensamento sobre o ensino [tese]. Rio de Janeiro: Universidade Federal do Rio de Janeiro; 2009.

20. Brasil. Ministério da Educação. Conselho Nacional de Educação. Câmara de Educação Superior. Diretrizes Curriculares Nacionais dos cursos de graduação. [acessado 2014 jun 21]. Disponível em: http://portal.mec. gov.br/index.php?option $=$ com_content\&id $=12991$ :diretrizes-curriculares-cursos-de-graduacao

21. Lucas SD, Palmier AC, Amaral JHL, Werneck MAF, Senna MIB. Inserção do aluno de odontologia no SUS: contribuições do Pró-Saúde. Rev ABENO 2012; 11(1):29-34.

22. Mialhe FL, Meneghim MDC, Souza MLR, Pereira AC. Integração ensino-serviço para a reorientação da formação profissional em saúde: a experiência da FOP/Unicamp. Rio de Janeiro: Usina de Letras; 2011.

23. Souza Neto AC, Almeida AL, Santos Junior PR, Novaes IM. Vivência da odontologia no PET-Saúde da Família da UFAL. Aprendizado de ações coletivas baseado no ensino-pesquisa-extensão acadêmicos. Rev ABENO 2012; 11(1):16-18.

24. Daher A, Costa LR, Machado GCM. Dental Students' Perceptions of Community-Based Education: A Retrospective Study at a Dental School in Brazil. J Dent Educ 2012; 76(9):1218-1225.

25. Batista MJ, Gibilini C, Kobayashi HM, Ferreira LL, Silva C, Rosário L. Relato de experiência da interação entre universidade, comunidade e Unidade de Saúde da Família em Piracicaba, SP. Arq Odontol 2010; 46(3):144151. 
26. Lefèvre F, Lefevre AM. Pesquisa de Representação Social: um enfoque qualiquantitativo: a metodologia do Discurso do Sujeito Coletivo. Brasília: Liber Livr; 2010.

27. Jodelet D. Representations sociales: un domaine en expansion. Paris: PUF; 1989.

28. Lefèvre F. O sujeito coletivo que fala. Interface (Botucatu) 2006; 10(20):517-524.

29. Brondani MA, Clark C, Rossoff L, Alekseju J. An Evolving Community-Based Dental Course on Professionalism and Community Service. J Dent Educ 2008; 72(10):1160-1168.

30. Brondani MA, Chen A, Chiu A, Gooch S, Ko K, Lee K, Maskan A, Steed B. Undergraduate geriatric education through community service learning. Gerodontology 2012; 29(2):E1222-E1229.

31. Craddock HL. An evaluation of student, patient and practitioner experience of general dental practice placements. Brit Dent J 2011; 211(6):279-282.

32. Eriksen HM, Bergdahl M, Byrkjeflot L-I, Crossner C-G, Widstrom E, Tillberg A. Evaluation of a dental outreach teaching programme. Eur J Dent Educ 2011; 15(1):3-7.

33. Elkind A, Watts C, Qualtrough A, Blinkhorn AS, Potter C, Duxbury J, Blinkhorn F, Taylor I, Turner R. The use of outreach clinics for teaching undergraduate restorative dentistry. Br Dent J 2007; 203(3):127-132.

34. Moimaz SAS, Saliba NA, Garbin CAS, Zina LG, Furtado JF, Amorin JA. Serviço extramuro odontológico: impacto na formação profissional. Pesq Bras Odontoped Clin Integr 2006; 8(41):53-57.

35. Lemos CLS. A implantação das Diretrizes Curriculares dos Cursos de Graduação em Odontologia no Brasil: algumas reflexões. Rev ABENO 2005; 5(1):80-85.

36. Moimaz SAS, Saliba NA, Garbin CAS, Zina LG. Atividades extramuros na ótica de egressos do curso de graduação em odontologia. Rev ABENO 2008; 8(1):23-29.

37. Morita MC, Codato LAB, Higasi MS, Kasai MLHI. Visita domiciliar: oportunidade de aprendizagem na graduação em Odontologia. Rev Odontol 2010; 39(2):7579.

38. Rubin RW. Developing cultural competence and social responsibility in preclinical dental students. J Dent Educ 2004; 68(4):460-467.

39. Maguire A, Hind V, Waterhouse PJ, Tabari D, Steen IN, Lloyd J. Developing a primary dental care outreach (PDCO) course - part 2: perceptions of dental students. Eur J Dent Educ 2009; 13(4):210-217.

40. Evans JL, Henderson A, Johnson NW. Interprofessional learning enhances knowledge of roles but is less able to shift attitudes: a case study from dental education. Eur J Dent Educ 2012; 16(4):239-245.
41. Evans CA, Bolden AJ, Hryhorczuk C, Noorullah K. Management of Experiences in Community- Based Dental Education. J Dent Educ 2010; 74(Supl. 10):25-32.

42. Morita MC, Haddad AE. Interfaces da área da Educação e da Saúde na perspectiva da formação e do trabalho das equipes de Saúde da Família. In: Moysés ST, Kriger L, Moysés SJ, organizadores. Saúde Bucal das Famílias. São Paulo: Artes Médicas; 2008. p. 268-276.

43. Cowpe J, Plasschaert A, Harzer W, Vinkka-Puhakka H, Walmsley AD. Profile and competences for the graduating European dentist - update 2009. Eur J Dent Educ 2010; 14(4):193-202.

44. Bauman Z. O mal estar da pós-modernidade. Rio de Janeiro: Zahar; 1998.

45. Araujo ME, Zilbovicius C. A formação acadêmica para o trabalho no Sistema Único de Saúde (SUS). In: Moysés ST, Kriger L, Moysés SJ, organizadores. Saúde Bucal das Famílias. São Paulo: Artes Médicas; 2008. p. 277290.

46. Atchison KA, Thind A, Carreon DC, Nakazono TT, Gutierrez JJ, Afifi AA, et al. Comparison of Extramural Clinical Rotation Days: Did the Pipeline Program Make a Difference? J Dent Educ 2011; 75(1):52-61.

47. Mascarenhas AK, Freilich SR, Henshaw MM, Jones JA, Mann ML, Frankl SN. Evaluating Externship Programs: Impact of Program Length on Clinical Productivity. J Dent Educ 2007; 71(4):516-523.

48. Santa-Rosa TTA, Vargas AMD, Ferreira EF. O internato rural e a formação de estudantes do curso de Odontologia da UFMG. Interface (Botucatu) 2007; 11(23):451466.

49. Ratzmann A, Wiesmann U, Gedrange T, Korda B. Early patient contact in undergraduate dental education in Germany - "The Greifswald Model". Eur J Dent Educ 2007; 11(2):93-98.

50. Smith M, Lennon MA, Brook AH, Ritucci L, Robinson PG. Student perspectives on their recent dental outreach placement experiences. Eur J Dent Educ 2006; 10(2):80-86

51. Warmling CM, Marzola NR, Botazzo C. Da autonomia da boca: práticas curriculares e identidade profissional na emergência do ensino brasileiro da odontologia. História, Ciências, Saúde - Manguinhos 2012; 19(1):181-195.

52. Houaiss A. Dicionário Houaiss da língua portuguesa. Rio de Janeiro: Objetiva; 2009.

Article submitted 07/10/2014

Approved 09/02/2014

Final version submitted 09/23/2014 
